\title{
Temporal changes in the biochemical composition of particulate organic matter sedimentation in the Bay of Banyuls-sur-Mer
}

\author{
Antoine GRÉMARE*, Jean-Michel AMOUROUX, François CHARLES, Laurence MEDERNACH, \\ Esther JORDANA, Christian NOZAIS, Gilles VETION, Jean-Charles COLOMINES \\ Laboratoire Arago, université Paris-VI, UMR CNRS 7621, BP 44, 66651 Banyuls-sur-Mer cedex, France \\ * gremare@ arago.obs-banyuls.fr
}

(Revised 11 June 1998, accepted 15 June 1998)

\begin{abstract}
Gross sedimentation rates (GSRs) were monitored together with meteorological data and the main biochemical characteristics of the collected material (i.e. organic content, C, N, total proteins, carbohydrates, lipids and available proteins) over a three year cycle at a shallow station $(18 \mathrm{~m})$ of the Bay of Banyuls, France. GSRs were between 0.26 (11/04/ $92)$ and $317.75 \mathrm{gDW} \mathrm{m}^{-2} \mathrm{~d}^{-1}(18 / 02 / 94)$. They followed an annual cycle with low and relatively constant values during spring and summer and high, variable values during fall and winter. During the study GSRs correlated poorly (state of the sea, precipitation) or even non-significantly (wind speed) with the main meteorological parameters. GSRs correlated negatively with the organic content of the material collected within the sediment traps suggesting the importance of resuspension in controlling GSRs. This hypothesis is consistent with the fact that, among all the measured biochemical parameters, available proteins (i.e. enzymatically hydrolizable proteins) are the most negatively correlated with GSRs. Available proteins showed important temporal changes that are only partly described by changes in carbon and nitrogen contents. These results are discussed in relation to the conceptualisation and the modelling of benthic trophic networks. The major objectives of our research group within the framework of the second phase of the French "Programme National d'Océanographie Côtière" are briefly discussed. () Elsevier, Paris
\end{abstract}

particulate organic matter / quality / temporal variability / coastal zone

Résumé - Variabilité de la composition biochimique des particules organiques en suspension dans la baie de Banyuls-sur-mer. Les taux de sédimentation brute (GSR) ont été mesurés avec les principaux paramètres météorologiques et les principales caractéristiques biochimiques (i.e. matière organique, C, N, protéines totales, hydrates de carbone, lipides et protéines disponibles) sur une période de trois ans à une station (18 $\mathrm{m}$ de profondeur) située en baie de Banyuls, France. Les GSR sont compris entre 0,26 (11/04/92) and $317,75 \mathrm{~g} \mathrm{~m}^{-2} \mathrm{j}^{-1}$ (18/02/94). Ils suivent un cycle annuel avec des valeurs faibles et relativement constantes durant la période printemps-été et des valeurs plus fortes et beaucoup plus variables durant la période automne-hiver. Les taux de sédimentation brute ne sont corrélés avec les paramètres météorologiques mesurés que faiblement (état de la mer, précipitation) ou même pas significativement (vitesse du vent). Les taux de sédimentation brute sont corrélés négativement avec les contenus organiques du matériel recueilli dans les pièges à particules, ce qui suggère l'importance du processus de resuspension dans le contrôle des taux de sédimentation brute. Cette hypothèse est en accord avec le fait que, parmi tous les paramètres biochimiques mesurés, les protéines disponibles (i.e. dégradables enzymatiquement) sont les plus négativement corrélées avec les taux de sédimentation brute. Les protéines disponibles montrent des variations temporelles importantes qui ne sont qu'imparfaitement décrites par les contenus en carbone et azote. Ces résultats sont discutés en relation avec la conceptualisation et la modélisation des réseaux trophiques benthiques. Les principaux objectifs de notre groupe lors de la seconde phase du Programme national d'océanographie côtière sont brièvement évoqués. (C) Elsevier, Paris

matière organique particulaire / qualité / variabilité temporelle / zone côtière 


\section{INTRODUCTION}

Once sedimented, particulate organic matter (POM) can be resuspended, buried, mineralised or incorporated within the benthic trophic network. The relative importance of these different pathways is strongly influenced by the biomass and the nature of the macrofauna present at the water-sediment interface. Macrofauna affects POM transfers either directly through nutrition, or indirectly through bioturbation. Benthic invertebrates are adapted to feed on relatively poor food sources [19] often resulting in very high ingestion rates and absorption efficiencies. At the population level for example, the amount of sediment ingested by deposit-feeding bivalves can reach as much as $100 \mathrm{~kg} \mathrm{~m}^{2} \mathrm{y}^{-1}$ (Grémare, unpublished), whereas the absorption efficiency of species fed on a living food source is usually higher than $50 \%$ [3]. Bioturbation is much more dependent on the ethology of the considered invertebrate. It seems usually low in the case of surface deposit-feeders [1], whereas conveyor belt deposit-feeders limit the burial of POM due to their feeding ethology [4] and enhance the exchange of nutrients at the watersediment interface due to the irrigation of their burrow $[17]$.

It is thus essential to understand the mechanisms controlling the abundance of macrofauna when modelling the transfers of POM at the water-sediment interface. This particular area of research has led to the development of models of benthic trophic networks $[2,8,9,25]$. These models are currently based on global descriptors of POM. and consequently they ignore the possibility of temporal changes in the quality of available POM [16]. This drawback is especially important: (1) for coastal arcas where the sedimented POM pool is highly heterogeneous [31]. and (2) when considering the nutrition of primary producers, which exploit potentially limited food sources [26]. One of the main aims of our research during the first phase of the French "Programme National d'Océanographie Côtière", was to assess the possible role of this source of (temporal) variability in the particular case of a Mediterranean benthic trophic network.

The assessment of short-term variability relative to the quality of the sedimenting POM required the implementation of a permanent site to ensure a high frequency sampling programme. This led us to install a permanent site within the Spisula subtruncata community in the Bay of Banyuls-sur-mer (western Mediterranean). This paper aims to synthesize the data collected on short-term variability in the biochemical composition of the POM sedi- mentation at this site during the first phase of the PNOC. The main perspectives induced by these results are briefly discussed.

\section{MATERIALS AND METHODS}

\subsection{Meteorological data}

Meteorological data (precipitation, state of the sea, wind speed and direction) were collected at the "MétéoFrance" station at Cape Béar.

\subsection{Sediment-trap}

Two sediment traps were deployed between $02 / 06 / 92$ and $30 / 05 / 95$ at a $18 \mathrm{~m}$ deep station $\left(42^{\circ} 29^{\prime} 082 \mathrm{~N}, 03^{\circ} 08^{\prime}\right.$ 421 E) located within the Bay of Banyuls-sur-mer (northwestern Mediterranean) (figure 1). Their main characteristics are provided in Charles et al. 111]. The mouths of the traps were located $3 \mathrm{~m}$ above the sediment surface.

\subsection{Biochemical assays}

The contents of the traps were collected weekly by scuba divers. They were centrifuged in the laboratory $(4000$ $\mathrm{rpm}, 3000 \mathrm{~g}, 15 \mathrm{~min}$ ), frozen, briefly rinsed with distilled water and freeze-dried prior to analysis. This material was then sieved on a $200 \mu \mathrm{m}$ mesh and stored at $-20^{\circ} \mathrm{C}$. Organic contents were assessed by measuring the weight loss after combustion $\left(450^{\circ} \mathrm{C}\right.$ for $\left.5 \mathrm{~h}\right)$. Carbon and nitrogen contents were measured using a $\mathrm{CHN}$ Perkin Elmer 2400 analyser. Protein contents were measured on triplicates using the Lowry procedure [20] as modified by Rice [27] to account for the reactivity of phenolic compounds. Available protein contents were measured on triplicates using the procedure proposed by Mayer et al. [24]. Carbohydrate contents were measured on triplicates using the procedure of Dubois et al. [13]. Lipid contents were measured on triplicates using the procedure of Barnes and Blackstock [5].

\section{RESULTS}

Monthly precipitation ranged between 1.2 (March 1994) and $306.5 \mathrm{~mm}$ (November 1993) (figure 2a). For the two years under study (i.e. 1993 and 1994), maxima were in the fall. Maximum monthly precipitation recorded in 1993 and 1994 were similar $(306.5$ and $283.6 \mathrm{~mm}$, respectively). The periods of rough sea were mostly 


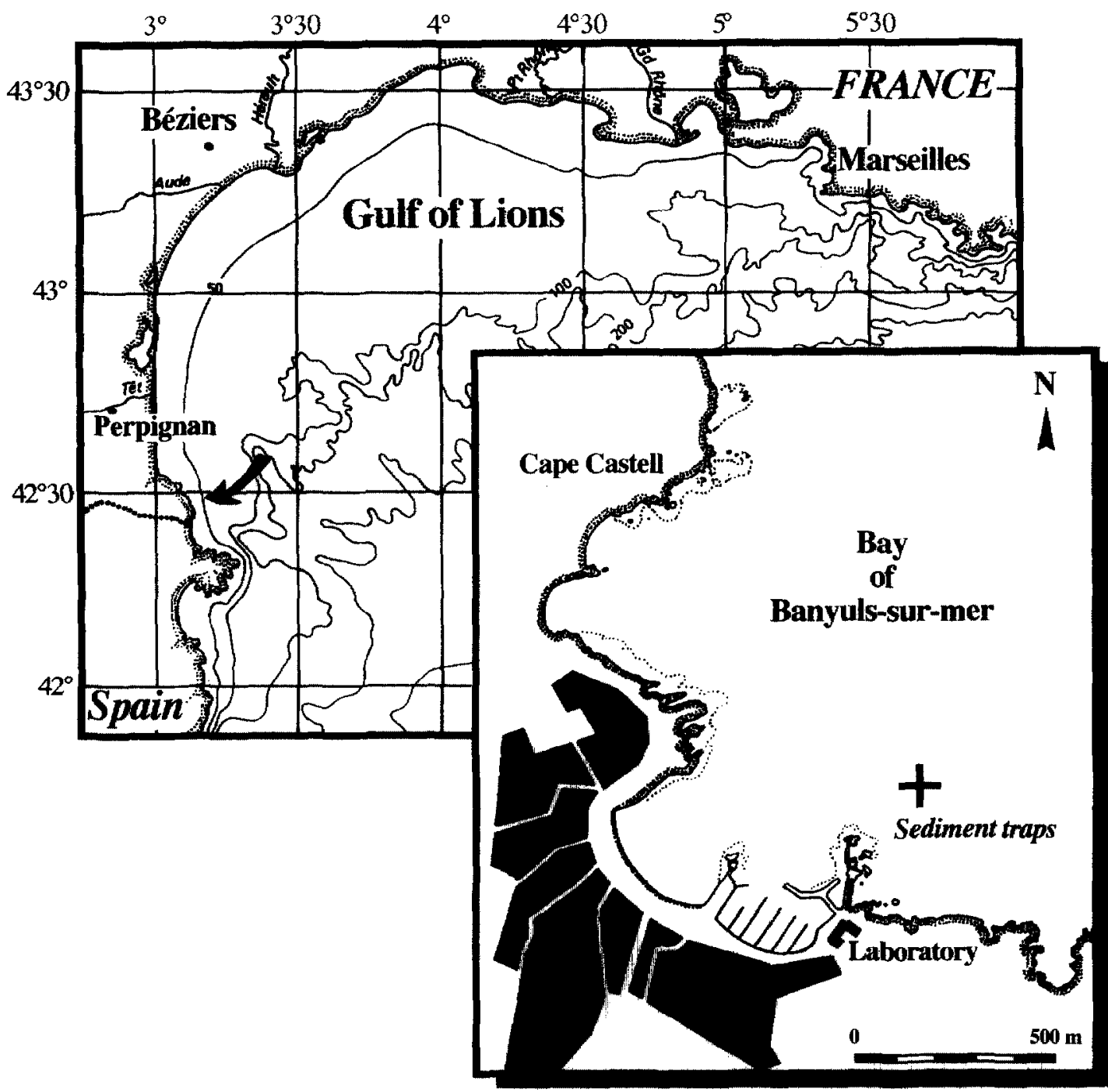

Figure 1. Map showing the location of the studied stations.

restricted to fall and winter (figure $2 b$ ). The roughest conditions were observed during the 1993-1994 winter. Maximum wind velocities are presented in figure $3 a$. They tended to be higher during fall and winter than during summer. Northerly winds were always dominant (figure $3 b$ ). This was especially true during summer, whereas during fall and winter they alternated with southerly wind episodes, often resulting in very rough sea and heavy rainfalls.

Sediment traps were recovered 145 times during the study period. Gross sedimentation rates (GSRs) were defined as the total amount of material sampled in a sediment trap with a known section are presented in figure $4 a$ ten GSRs were between $0.26(11 / 04 / 1992)$ and 317.75 gDW $\mathrm{m}^{-2} \mathrm{~d}^{-1}$ (18/02/94). GSRs followed an annual cycle (apparent period of 52 weeks, perjodogram not shown). Within each of the three studied years, it was possible to distinguish two different periods. The first one was characterised by relatively low and constant GSRs. It corresponded mainly to spring and summer. The second one was characterised by relatively high and highly variable GSRs and corresponded mainly to fall and winter. The durations of these two periods differed between years $(28,18$ and 30 weeks respectively for the period characterised by high GSRs). Average GSRs recorded during fall and winter differed significantly from year to year (One-WAY ANOVA, $p<0.01$ ) due to lower values dur- 


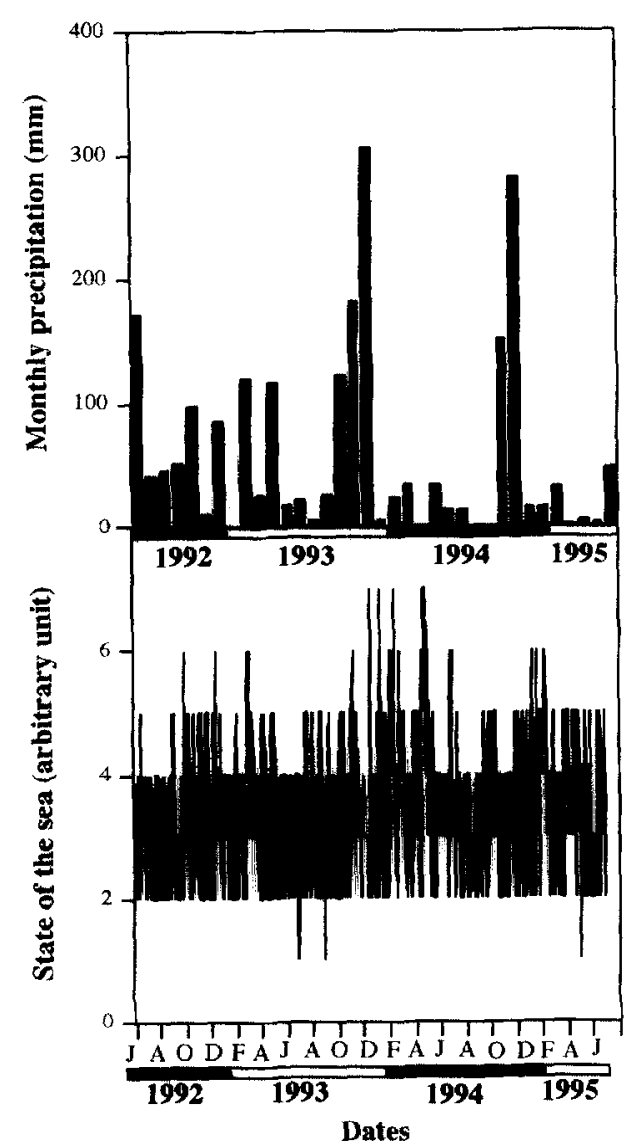

Figure 2. Meteorological data. Precipitation (monthly observations) and state of the sea (daily observations) during the period under study.

ing the third year (a posteriori Fisher LSD test, $p<0.05$ ). The highest GSRs were recorded during the 1993-1994 fall and winter period. Average GSRs recorded during spring and summer showed no significant differences for the different years (One-WAY ANOVA, $p=0.42$ ). The correlations between GSRs and the main meteorological parameters are presented in table I. GSRs were not significantly correlated with wind speeds whereas both state of the sea and precipitation only accounted for a small portion of their variance $(7.7$ and $28.5 \%$, respectively).

Organic contents ranged from $5.47(17 / 01 / 95)$ to $24.53 \%$ DW (08/03/95) (figure $4 b$ ). They followed an annual cycle (apparent period of 52 weeks, periodogram not shown). When pooling the results of the three years under study, GSRs correlated negatively with organic contents (figure 5 and table $I I$ ). It was not possible to compare the characteristics of this regression for different years [16] due to the low range of variation of GSRs during the third year under study (see below).

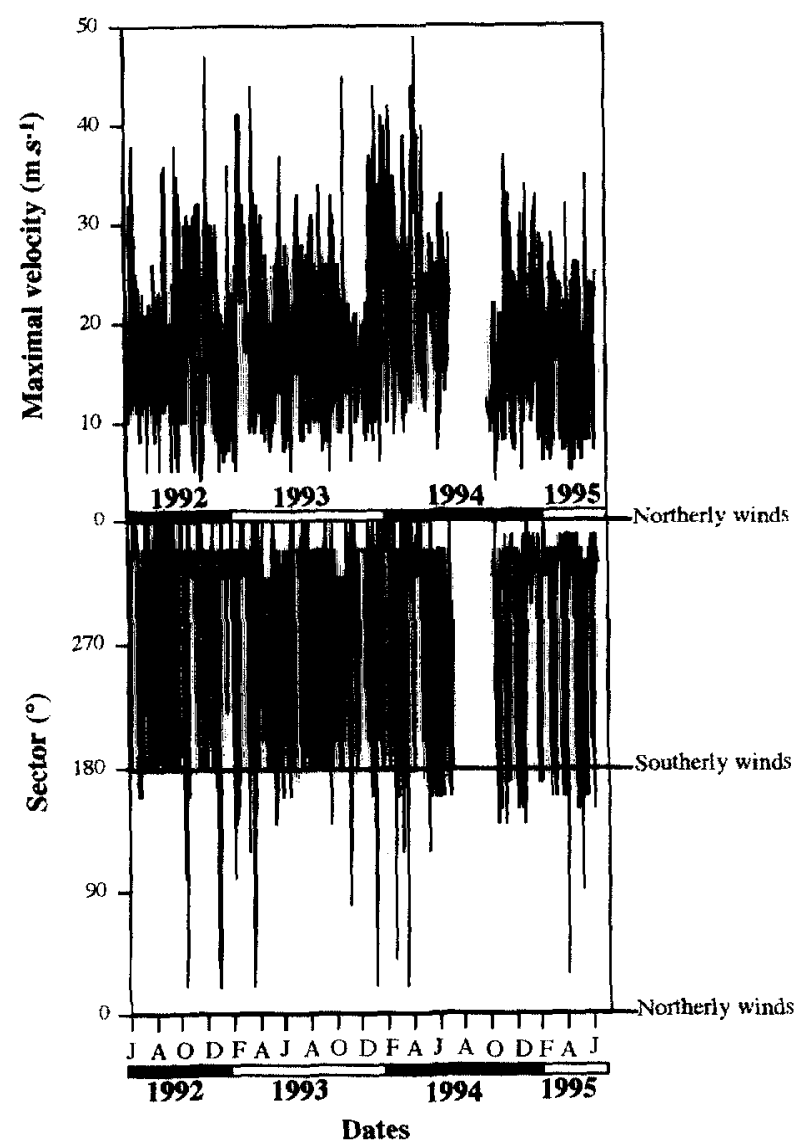

Figure 3. Meteorological data. Maximum wind speed (daily observations) and corresponding sector during the period under study.

Carbon and nitrogen contents of the sediment trap materials are presented in figure 6 together with the corresponding $\mathrm{C} / \mathrm{N}$ ratios. Carbon contents ranged from 2.45 $(02 / 03 / 93)$ to $8.73 \% \mathrm{DW}$ (18/08/92). Nitrogen contents ranged from 0.09 (13/10/92) to $0.94 \% \mathrm{DW}(09 / 08 / 94)$. Both of these parameters followed an annual cycle (apparent period of 50 weeks, periodograms not shown). $\mathrm{C} / \mathrm{N}$ ratios fluctuated around a mean value of 11 with the occurrence of exceptionally high values during the second half of October 1992.

Table I. Determination coefficients of linear regression models linking gross sedimentation rates and states of the sea, wind speeds (weekly observations), and precipitation (monthly observations *: $\mathrm{p}<0.01,{ }^{* *}: \mathrm{p}<0.001,{ }^{* * *}, \mathrm{p}<0.0001$.

\begin{tabular}{lccc}
\hline Meteorological parameter & $\mathbf{N}$ & $\mathbf{r}^{2}$ & $\mathbf{p}$ \\
\hline State of the sea & 144 & 0.077 & $* *$ \\
Wind speed & 132 & 0.053 & NS \\
Precipitation & 36 & 0.285 & $* *$ \\
\hline
\end{tabular}




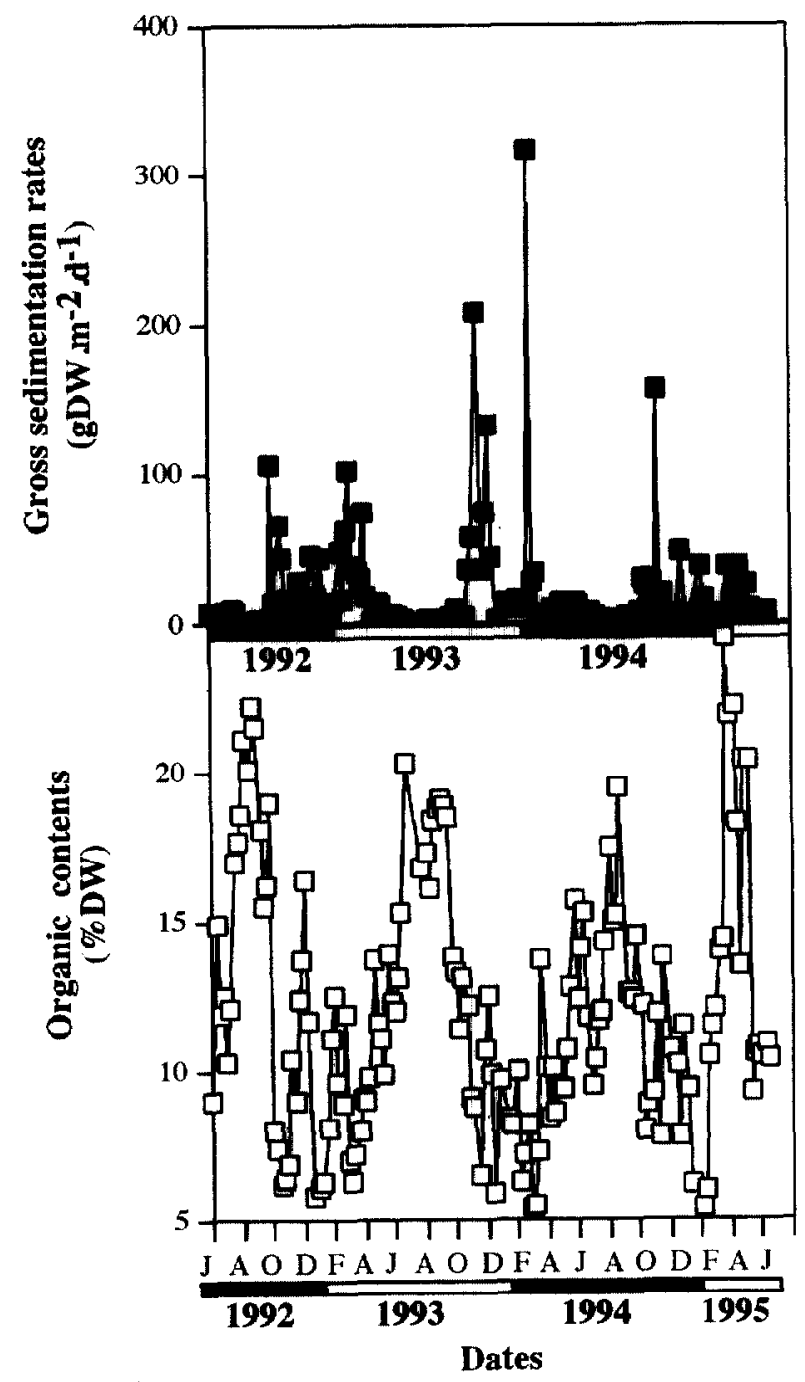

Figure 4. Sediment traps. Temporal changes of gross sedimentation rates and organic contents.

Carbohydrate and lipid contents of the sediment trap materials are presented in figure 7 . Carbohydrate contents ranged from $13.0(07 / 12 / 93)$ to $77.7 \mu \mathrm{g}(\mathrm{mgDW})^{-1}(17 /$ 08/93). Lipid concentrations ranged from $0.8(05 / 01 / 93)$ to $35.4 \mu \mathrm{g}(\mathrm{mgDW})^{-1}(13 / 04 / 93)$. Both of these parameters followed an annual cycle (apparent periods of 52 and 43 weeks, respectively, periodograms not shown) although this pattern seemed less clear for lipids, largely due to the low values recorded during the summer of 1994.

Total protein and available protein contents of the sediment trap materials are presented in figure 8 . Total protein concentrations ranged from $1.9(02 / 03 / 93)$ to

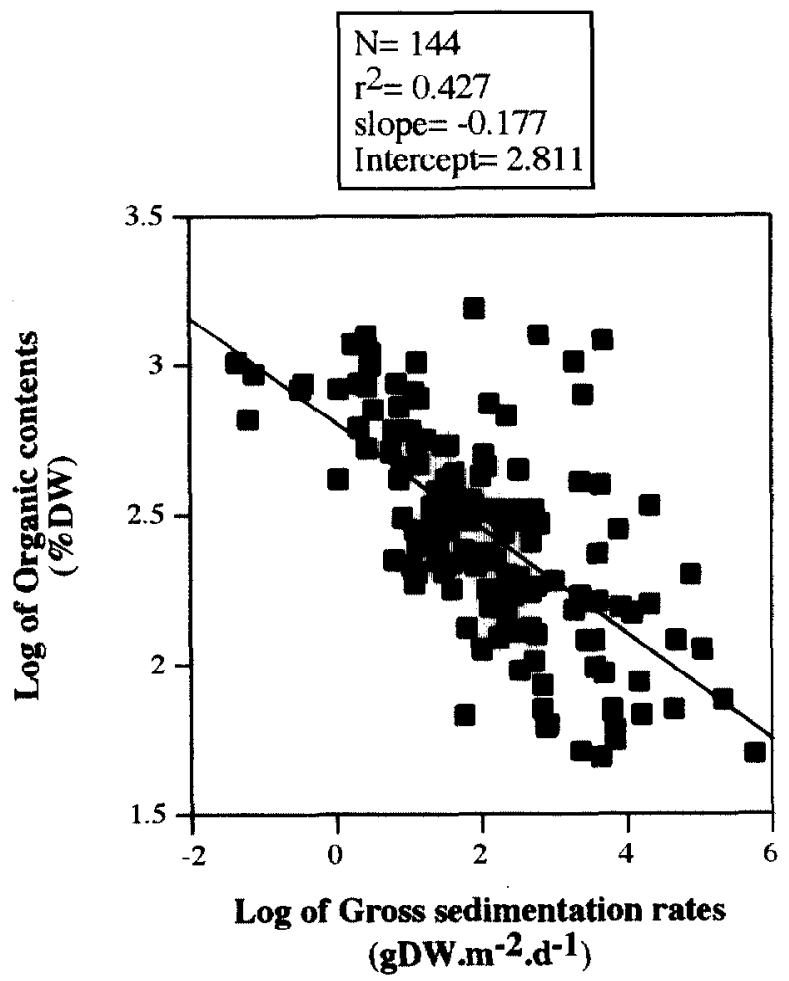

Figure 5. Sediment traps. Relationship between organic contents and gross sedimentation rates during the period under study.

$35.1 \mu \mathrm{g}(\mathrm{mgDW})^{-1}(08 / 03 / 94)$. Available protein contents ranged from 0.34 (17/01/95) to $21.87 \mu \mathrm{g}$ (mgDW) ' (28/ 07/92). Both of these parameters seemed to follow an annual cycle (apparent period of 43 and 52 weeks, respectively, periodograms not shown). Among the tested biochemical parameters, available proteins were the most negatively correlated with GSRs (table II). The aptitudes of the other biochemical parameters to describe changes in available proteins through simple linear regression models are summarised in table III. Carbon and nitrogen were the best descriptors of available protein contents, accounting for about $75 \%$ of observed variance.

\section{DISCUSSION}

\subsection{Gross sedimentation rates}

GSRs recorded during the study ranged between 0.26 and $317.75 \mathrm{gDW} \mathrm{m}^{-2} \mathrm{~d}^{-1}$. These values can be compared with similar data regarding a $30 \mathrm{~m}$-deep station located at Saint-Cyprien (about $25 \mathrm{~km}$ north of our own station) [6]. This author reported GSRs very similar to ours with values ranging from 4.5 to $319.0 \mathrm{gDW} \mathrm{m}^{-2} \mathrm{~d}^{-1}$. GSRs 


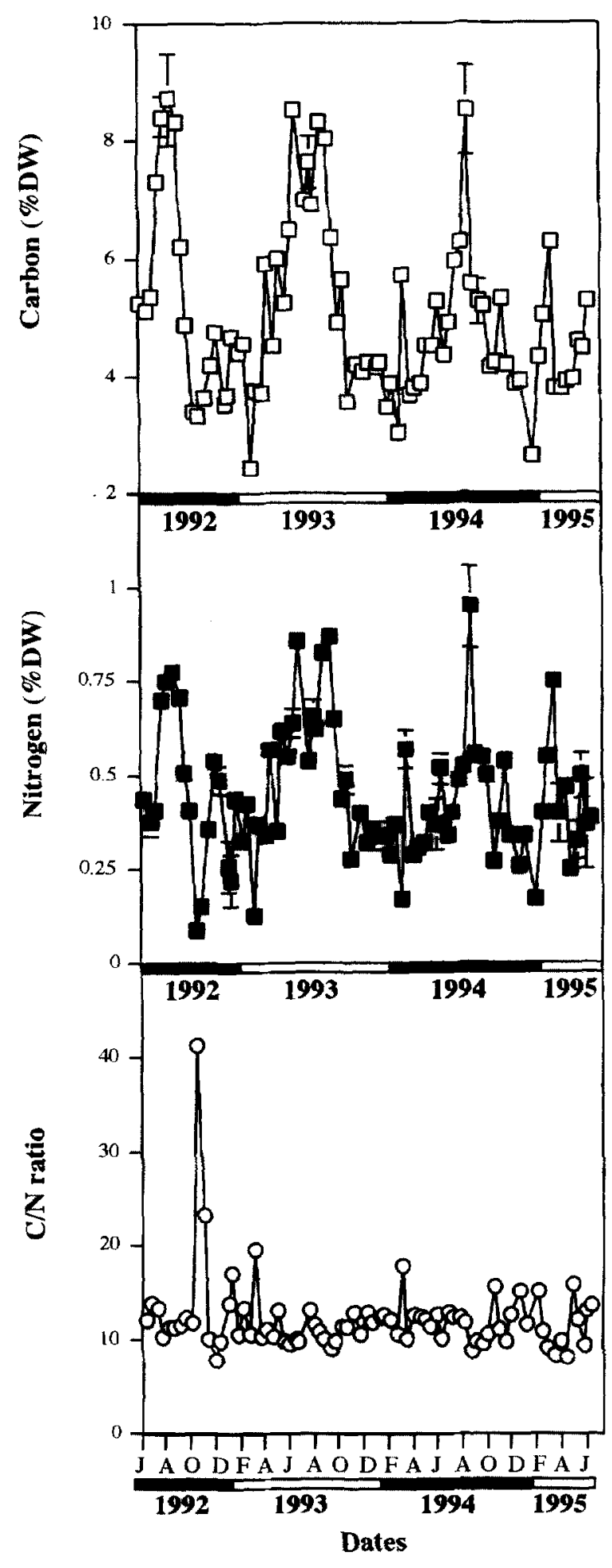

Figure 6. Sediment traps. Temporal changes of carbon contents, nitrogen contents, and corresponding $\mathrm{C} / \mathrm{N}$ ratios.

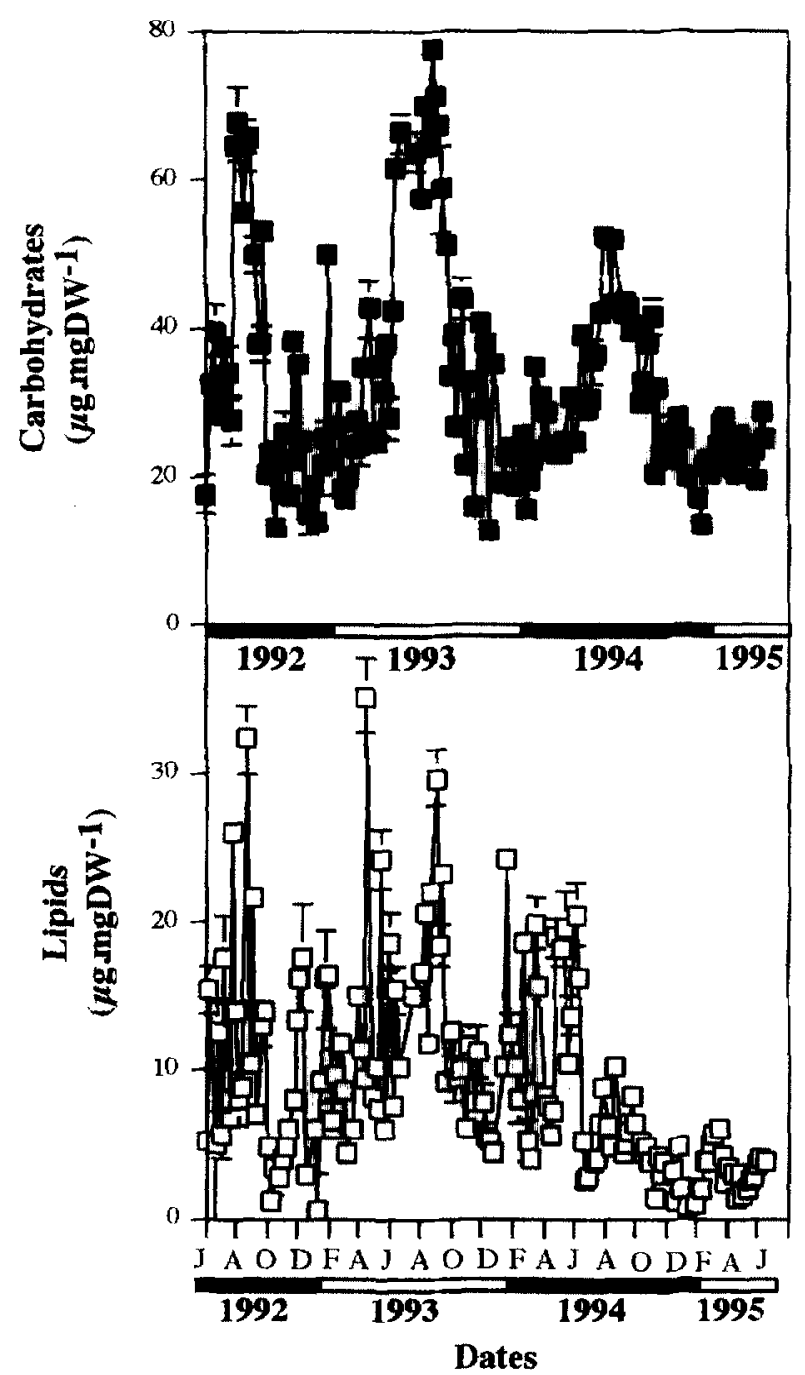

Figure 7. Sediment traps. Temporal changes of the carbohydrate and lipid contents.

varied strongly and with a seasonal component. They were usually high during fall and winter, and low during spring and summer. These results are similar to those reported by Lund-Hansen et al. [21] for the transition between the North Sea and the Baltic where this pattern turned out to be mainly cued by meteorological events.

During the study, the highest GSRs were recorded during the 1993-1994 winter together with the roughest sea conditions. Moreover, our results showed a negative correlation between the organic content of the sediment trap materials and GSRs. The shape of this relationship is similar to what could be obtained by simply diluting a food characterised by a (relatively) high organic content in a poorer source of organic matter. These results sug- 


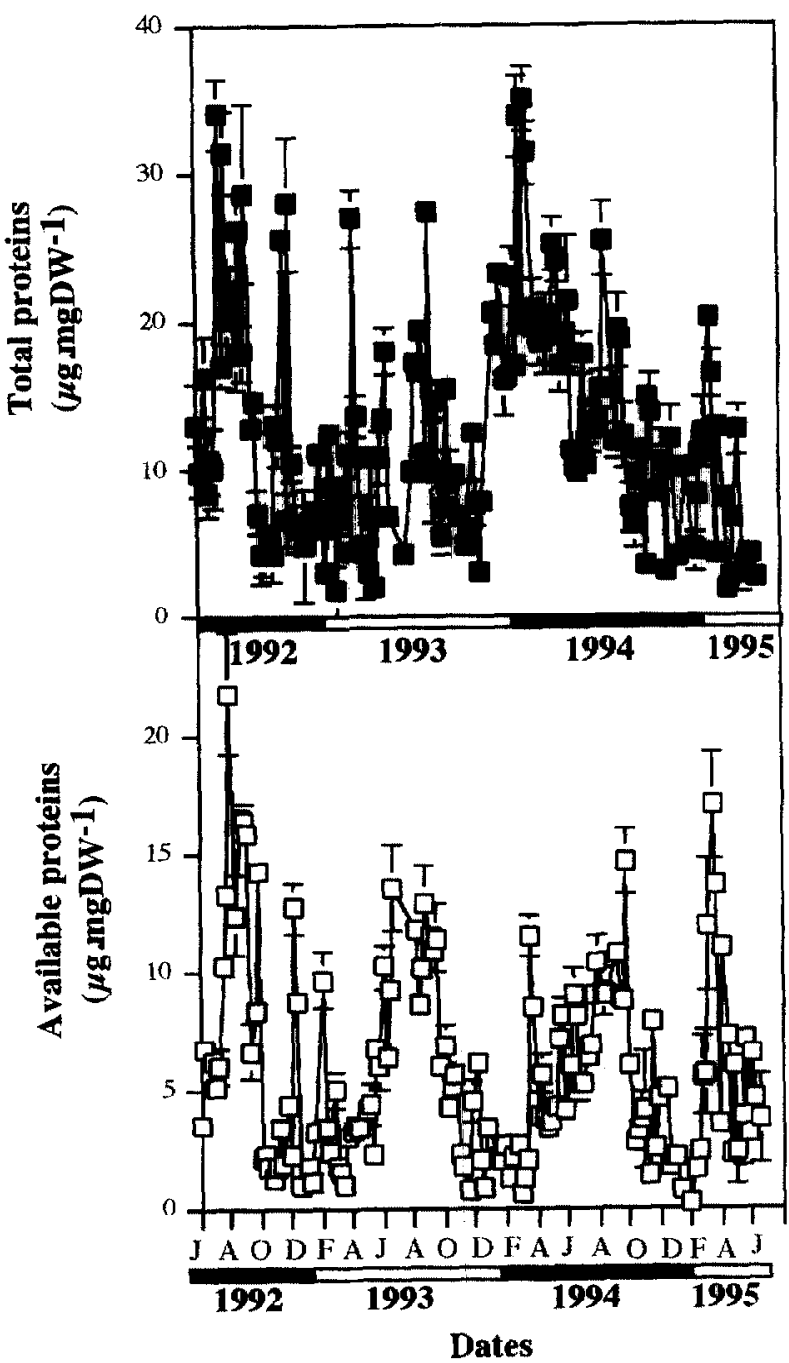

Figure 8. Sediment traps. Temporal changes of the total and available protein contents.

gest that resuspension may contribute to a large extent to fluctuations in GSRs recorded at the station studied. Within the Bay of Banyuls-sur-mer, resuspension events are mainly triggered by the swell originating from strong depressions located far eastward (A.G. and J.M.A. personal observations). Such events usually do not correspond to a specific meteorological signature within the Banyuls area, which might explain the lack of lit of the regression models linking local meteorological conditions (i.e. wind and precipitation) and GSRs, which was already reported for a much shorter time series [11]. This pattern results in strong and impulsional resuspension events which mix the upper layer of sediment. The frequency of occurrence of such events is much higher dur-
Table II. Determination coefficients of simple Log-Log regression models linking gross sedimentation rates and several biochemical parameters of the sediment trap collected material. Table IlA refers to the whole data set. Table IIB refers to a common number of observations for the sake of comparison between parameters. OM: Organic matter, C: carbon, N: nitrogen, NS: $p>0.01,{ }^{*}: \mathrm{p}<0.01$, $* *: p<0.001, * * *: p<0.0001$.

\begin{tabular}{|c|c|c|c|}
\hline $\begin{array}{l}\text { Biochemical } \\
\text { parameter }\end{array}$ & $\mathbf{N}$ & $\mathbf{r}^{2}$ & $\mathbf{p}$ \\
\hline OM & 144 & 0.427 & *** \\
\hline $\mathrm{C}$ & 77 & 0.461 & $\% *$ \\
\hline$N$ & 77 & 0.360 & $* * *$ \\
\hline Total proteins & 145 & 0.100 & 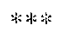 \\
\hline Available proteins & 140 & 0.538 & $* * *$ \\
\hline Carbohydrates & 145 & 0.412 & $x * *$ \\
\hline Lipids & 145 & 0.107 & $* * * *$ \\
\hline \multicolumn{4}{|l|}{ B } \\
\hline $\begin{array}{l}\text { Biochemical } \\
\text { parameter }\end{array}$ & $\mathbf{N}$ & $\mathrm{r}^{2}$ & $\mathbf{p}$ \\
\hline$\overline{\mathrm{OM}}$ & 72 & 0.381 & ***** \\
\hline $\mathrm{C}$ & 72 & 0.404 & $* * * *$ \\
\hline$N$ & 72 & 0.320 & 米: \\
\hline Total proteins & 72 & 0.074 & NS \\
\hline Available proteins & 72 & 0.425 & 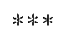 \\
\hline Carbohydrates & 72 & 0.272 & $* * *$ \\
\hline Lipids & 72 & 0.058 & $* ; * *$ \\
\hline
\end{tabular}

ing fall and winter than during spring and summer when the inputs originating from the water column are probably more important due to a constant phytoplanktonic bloom in May [18].

\subsection{Biochemical assays and the assessment of POM quality}

In his review on nutritional requirements of detritivores, Phillips [26] has shown that benthic primary consumers cxploit several food sources of different biochemical compositions. As opposed to macroheterotrophs, the contents in essential aminoacids can vary greatly from one type of primary producer to another. Moreover, each main category of primary producers may lack one or sev. cral essential micronutrients [26]. This explains: (1) why primary consumers are so dependent on the quality of their food, and (2) why the concepts of food quality and biochemical composition are so closely related.

Bioassays have been commonly used to provide an empirical assessment of food quality $[11,12,16,29,30]$. 
Table III. Determination coefficients of simple linear regression models linking available proteins and several other biochemical parameters of the sediment trap collected material. Table IIIA refers to the whole data set. Table IIIB refers to a common number of observation for the sake of comparison between parameters. OM: Organic matter, $\mathrm{C}$ : carbon, $\mathrm{N}$ : nitrogen. NS: $\mathrm{p}>0.01,{ }^{*}: \mathrm{p}<0.01$, $* *: \mathrm{p}<0.001, * * *: \mathrm{p}<0.0001$.

A

\begin{tabular}{lccc}
\hline Biochemical parameter & $\mathbf{N}$ & $\mathbf{r}^{2}$ & $\mathbf{p}$ \\
\hline OM & 139 & 0.638 & $* * *$ \\
C & 72 & 0.767 & $* * *$ \\
N & 72 & 0.734 & $* * *$ \\
TotaJ proteins & 140 & 0.265 & $* * *$ \\
Carbohydrates & 140 & 0.499 & $* * *$ \\
Lipids & 140 & 0.220 & $* * *$ \\
\hline
\end{tabular}

\section{B}

\begin{tabular}{lccc}
\hline Biochemical parameter & $\mathbf{N}$ & $\mathbf{r}^{\mathbf{2}}$ & $\mathbf{p}$ \\
\hline OM & 72 & 0.606 & $* * * *$ \\
$\mathrm{C}$ & 72 & 0.767 & $* * *$ \\
$\mathrm{~N}$ & 72 & 0.734 & $* * *$ \\
Total proteins & 72 & 0.150 & $* *$ \\
Carbohydrates & 72 & 0.434 & $* * *$ \\
Lipids & 72 & 0.288 & $* * *$ \\
\hline
\end{tabular}

However the results of such tests are only semi-quantitative and remain difficult to transpose to other systems and other time periods than the ones used during the bioassays. It is interesting to relate direct qualitative assessments through bioassays with the biochemical compositions of the tested substrates $[14,16,26]$. Both nutritional physiology and limiting factor theory provide the theoretical baseline for that (see [14] and references therein).

Nitrogen is commonly thought to be the limiting factor in detritic food chains $[7,31]$. It is now recognised that a large proportion of sediment nitrogen is bound into refractory materials and thus cannot be utilised by benthic invertebrates $[24,27]$. It seems useless to correlate nutritional performances of living organisms with total nitrogen or protein contents. This is why considerable efforts have been made to develop analytical protocols designed to quantify that particular proportion of the total nitrogen pool which is actually available to the benthic fauna $[23,24]$.

These procedures involve enzymatic hydrolysis aimed at mimicking digestion $[23,24]$. During the first phase of the PNOC, we associated bioassays (i.e. growth experi- ments carried out with the bivalve Abra ovata) and biochemical assays to compare the ability of several biochemical parameters to describe the variance of observed growth rates [16]. Our results showed that available proteins constitute a much better descriptor of growth than total proteins or nitrogen. They thus support the "biomimetic" approach devcloped by Mayer ct al. $[23,24]$ for the quantification of bioavailable nitrogenous compounds. Given this, it seems that available proteins can indeed be used as an index of the quality of sedimenting POM [16].

Results from the present study show that this parameter features important temporal changes, and is significantly correlated with global biochemical descriptors of organic matter such as carbon and nitrogen. However such global descriptors of organic matter account for only $75 \%$ of the variance of available proteins (and probably much less if we considered the results of empirical assessment of POM quality through bioassays). Thus our results confirm the existence of important temporal changes in the quality of sedimenting POM as already evidenced by bioassays involving either growth or absorption measurements $[11,16]$, and suggest that available proteins should be incorporated in benthic trophic network models to describe the production of benthic primary consumers as suggested by Grémare et al. [16].

\subsection{Real impact on the functioning of benthic trophic network: the sampling problem}

During this study, POM was sampled in sediment traps. The observed qualitative changes refer to sedimenting POM and may overestimate what happens in the sediment itself due to accumulation and dilution. The first thing to point out is that temporal changes in sediment quality have already been reported by Cheng et al. [12] who compared the nutritional values of sediment collected during spring or early summer and fall by measuring the population response of the oligochaete Paranais littoralis. This is confirmed by some of our own observations regarding the studied site (Grémare, unpublished).

The importance of sediment accumulation is obviously affected by hydrodynamism, which also largely controls sediment granulometry and feeding characteristics of benthic organisms. During this study, we were working on a sandy bottom where sediment accumulation is low and filter-feeders are largely dominant [15]. In this sense, sampling using sediment traps was probably more repre- 
sentative of the POM available for the dominant invertebrates than sediment cores. Furthermore, seasonal changes in hydrodynamism may also contribute to increased temporal changes. For example, a constant and strong resuspension would contribute to reducing differences in the quality of the inputs by mixing the first few centimetres of sediment. At the study site, this is what basically takes place during fall and winter. One can thus suppose that during this particular period, differences in the quality of sedimenting POM have a limited effect on the quality of sedimented POM. In contrast, resuspension is almost zero during spring and summer. Thus, this process (1) does not reduce differences in the quality of sedimenting POM during this period, and (2) tends to increase differences observed between fall and winter, and between spring and summer.

Lastly, it should be stressed that the sampling of POM is a general problem when studying the nutrition of benthic organisms. Even when working with sediment cores, we can never be sure that benthic organisms are indeed feeding on the precise portion of sediment that we are assaying. In fact, because of large differences in feeding modes, they probably do not. Deposit-feeders for example are classically divided into surface and conveyor-belt. which feed at very different depths, whereas the term surface deposit-feeder encompasses very different feeding behaviour (including interface-fecders).

\section{CONCLUSIONS AND PERSPECTIVES}

\subsection{Resuspension}

Results from the present study revealed important temporal changes in the quality of the POM collected within the sediment traps. At the studied site this clearly results from an interaction between pelagic primary production and resuspension. This last parameter is still difficult to quantify, and would require the monitoring of several physical parameters including pressure, water turbidity and current velocity at different depths. One of our objectives during the second phase of the French "Programme National d'Océanographie Côtière" will be to develop a multidiciplinary approach to this particular problem. In this context, we believe that the acquisition of a high-frequency time series at a permanent site would prove very valuable.

\subsection{Response of benthic ecosystems to sedimentation}

Apart from resuspension, which complicates the assessment of vertical fluxes in the coastal zone, the assessment of POM quality constitutes another problem accounting for the difficulty of linking the response of benthic fauna to vertical fluxes. This is well illustrated by the impossibility of describing major events of the benthos dynamics such as the seasonal decline of populations of opportunistic deposit-feeders in estuarine environments by using encrgy balances based on macronutrients [22]. As shown above, available proteins can be used as an index of POM quality. Together with the effort made in our laboratory to build a benthic lander allowing in situ oxygen measurements and incubations [28], this allows our group to analyse the response of benthic ecosystems to sedimentation regimes differing both in quantity and quality. For the continental shelf, this particular effort will be made in the second phase of the French "Programme national d'océanographie côtière". It will involve (1) the pursuit of the operations regarding the permanent site, (2) cruises designed to assess seasonal variability along a depth gradient (BBLL), and (3) another series of cruises aiming at quantifying spatial variability (MOOGLI).

\section{Acknowledgements}

The support of the Mediterranean component of the biogeochemical project of the French National Program of Coastal Oceanography (PNOC) is gratefully acknowledged.

\section{REFERENCES}

[1] Alongi D.M., Effect of physical disturbance on population dynamics and trophic interactions among microbes and meiofauna, J. Mar. Res. 43 (1985) 351-364
[2] Ameziane N., Chardy P., Dauvin J.-C., Modelling carbon flows in soft-bottom communities from the Bay of Morlaix western English Channel. in; Biology and Ecology of shallow. 
coastal waters, Proceeding of the 28th EMBS. Eleftheriou A., Ansell A.D., Smith C.J. (Eds), Olsen and Olsen, Fredensborg, $1995,215-224$.

[3] Amouroux J.-M., Grémare A.. Amouroux J., Modeling of consumption and assimilation in Abra alba (Mollusca, Bivalvia), Mar. Ecol. Prog. Ser. 51 (1989) 87-97.

[4] Bianchi T.S., Feeding ecology of subsurface deposit-feeder Leithoscoloplos fragihis Verrill. 1, Mechanisms affecting particle availability on intertidal sandflat, J. Exp. Mar. Biol. Ecol. 115 (1988) 79-87.

[5] Barnes H., Blackstock J., Estimation of lipids in marine animals and tissues: detailed investigations of the sulphosphovanillin method for "total" lipids, J. Exp. Mar. Biol. Ecol. 12 (1973) 103-118.

[6] Buscail R., Le cycle du carbone sur une marge continentale: aspects biogéochimiques du transfert de la matière organique à l'interface eau-sédiment, Thèse Doct. Etat, Univ. Perpignan (1991) $1-642$.

[7] Carey D.A., Mayer L.M., Nutrient uptake by a deposit-feeding enteropneust: nitrogenous sources, Mar. Ecol. Prog. Ser. 63 (1990) 79-84.

[8] Chardy P., Modèle de simulation du système benthique des sédiments grossiers du golfe normand-breton (Manche). Oceanol. Acta 10 (1987) 421-434.

[9| Chardy P., Dauvin J.C., Carbon flows in a subtidal fine Sand community from the western English Channel: a simulation analysis, Mar. Ecol. Prog. Ser 81 (1992) 147-161.

[10] Chardy P., Gros P., Mercier H., Montbet Y.. Benthic carbon budget for the Bay of Saint-Brieuc western Channel), Application of inverse method. Occanol. Acta 16 (1993) 687-694.

[11] Charles F., Grémare A., Amouroux J.-M., Baudart J., A bioassay approach to temporal variation in the nutritional value of sediment trap material, J. Exp. Mar. Biol. Ecol. 19 (1995) 6581.

[12] Cheng I.J., Levinton J.S., McCartney M., Martinez D., Weissburg M.J., A bicassay approach to seasonal variation in the nutritional value of sediment, Mar. Ecol. Prog. Ser. 94 (1993) $275-285$

[13] Dubois M., Gilles K.A., Hamilton J.K., Rebers P.A., Smith F., Colorimetric method for determination of sugars and related substances. Anal. Chem. 26 (1956) 350-356.

[14] Grémare A., What describes fecundity of Capitella sp. I better: macro- and micronutrients? Mar. Biol. 102 (1994) 519-527.

[15] Grémare A., Amouroux J-M., Vétion G., Long-term comparison of macrobenthos within the soft bottoms of the Bay of Banyuls-sur-mer (northwestern Mediterranean sea), Deep-Sea Res. (In press).

16] Grémare A., Amouroux J.-M., Charles F.. Dinet A.. RiauxGobin C., Baudart J.. Medernach L., Bodiou J.Y., Vétion G., Colomines J,-C., Albert P., Temporal changes in the biochemical composition and nutritional value of the particulate organic matter available to surface deposit-feeders; a two year study, Mar. Ecol. Prog. Ser 150) (1997) 195-206
[17] Huttel M., Influence of the lugworm Arenicola marina on porewater nutrient profiles of sand flat sediments, Mar. Ecol. Prog. Ser. 62 (1990) 241-248.

[18] Jacques G., Aspects quantitatifs du phytoplancton de la région de Banyuls-sur-mer (Golfe du Lion) 1965-1969, Thèse de doctorat d'État, Faculté des Sciences de Paris (1970) 1-201.

[19] Lopez G.R. Levinton J.S., Ecology of deposit-feeding animals in marine sediments, Quart. Rev. Biol. 62 (1987) 235-260.

[20] Lowry O.H., Rosebrough N.J., Fart A.L., Randall R.J., Protein measurement with the Folin phenol reagent, J. Biot. Chem. 193 (1951) 265-275.

[21] Lund-Hansen L. C., Pejrup M., Valeur J., Jensen A., Gross sedimentation rates in the North Sea-Baltic Sea transition: effecls of stratification, wind energy transfer and resuspension. Oceanol. Acta 16 (1993) 205-212.

[22] Marsh A.G., Tenore K.R., The role of nutrition in regulating the population dynamics of opportunistic surface deposit-feeders in a mesohaline community, Limnol. Oceanogr. 35 (1990) $710-724$.

23] Mayer L.M., Schick L.L., Sawyer T., Plante C.J., Jumars P.A., Self R.L., Bioavailable amino acids in sediments: a biomimetic kinetic-based approach, Limnol. Oceanogr. 40 (1995) $511-$ 520 .

[24] Mayer L.M., Schick L.L., Setchell F.W., Measurement of protein in nearshore marine sediments, Mar. Ecol. Prog. Ser. 30 (1986) $159-165$

[25] Pace M.L., Glasser J.E., Pomeroy L.R., Simulation analysis of continental shelf food webs, Mar. Biol. 82 (1984) 47-63.

[26] Phillips N.W., Role of different microbes and substrates as potential suppliers of specific essential nutrients to marine detritivores, Bull. Mar. Sci. 35 (1984) 283-298.

[27] Rice D.L.. The detritus nitrogen problem: new observations and perspectives from organic geochemistry. Mar. Ecol. Prog. Ser. 9 (1982) 153-162.

[28] Tengberg A.. Bovée de F., Hall P., Berelson W., Cicceri G., Crassous P., Devol A., Emerson S., Glud R., Graziottin F., Gundersen J., Hammond D., Helder W., Hinga K., Holby O., Jabnke R., Kripounoff A., Nupeneau V., Pfannkuche O., Rei mers C., Rowe G., Sahami A., Sayles F., Schurter M., Smallman D., Wehrli B., Benthic chamber and profiling landers in oceanography. A review of design, technical solutions and functioning, Prog. Oceanogr. 35 (1995) 253-294.

[29] Tenore K.R., Organic nitrogen and caloric content of deritus. 1. Utilization by the deposit-feeding polychaete Capitella capitata. Estuar. Coast. Shelf Sci. 12 (1981) 39-47.

[30] Tenore K.R., What controls the availability to animals of detritus derived from vascular plants: organic nitrogen enrichment or caloric availability? Mar. Ecol. Prog. Ser. 10 (1983) $307-$ 309 .

[31] Tenore K.R.. Nitrogen in Benthic Food Chains, in: Blackbum T.H., Sorensen J. (Eds), Nitrogen Cycling in coastal environment, Scope, J. Wiley \& Sons Ltd, London, 1988, 191-206. 